\title{
"The hours and times of your desire": Sholto Smith's romantic vision for Colwyn (1925)
}

Linda Tyler, Centre for New Zealand Art Research and Discovery, National Institute of Creative Arts and Industries, University of Auckland, Auckland

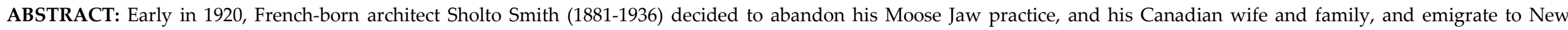

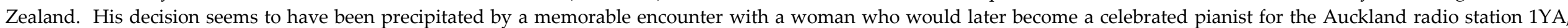

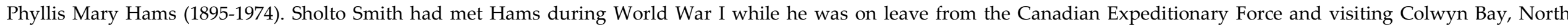

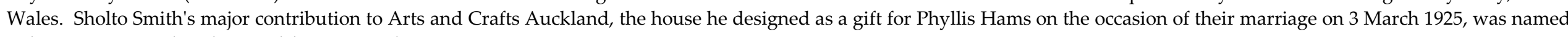
Colwyn to memorialise their Welsh meeting place.

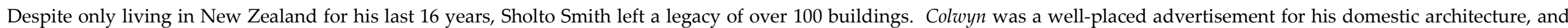

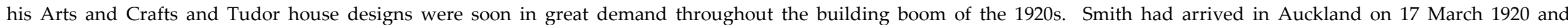

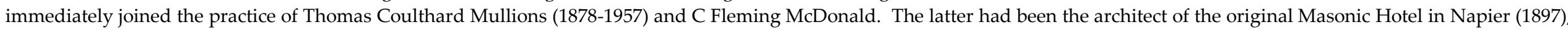

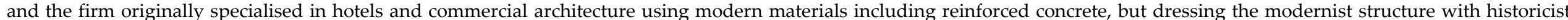

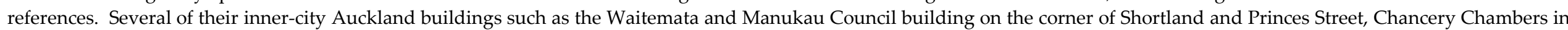

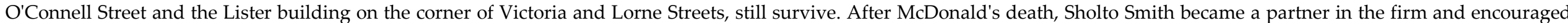

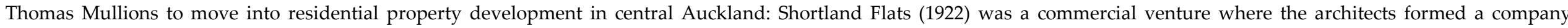
owning shares in the building which comprised 24 flats designed to generate rental income.

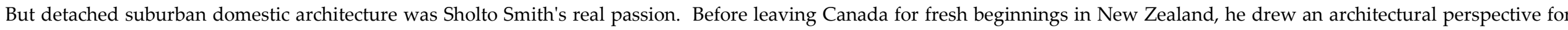

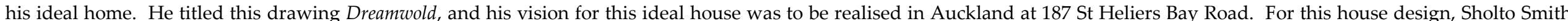

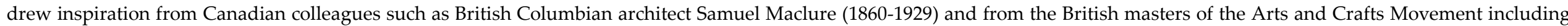

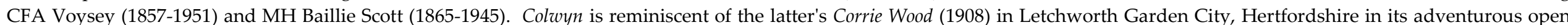
planning.

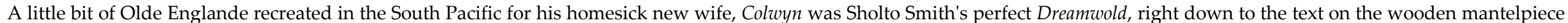

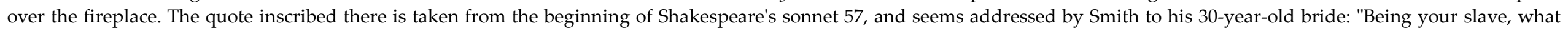

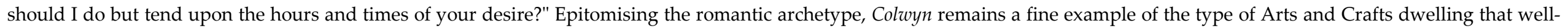
to-do Aucklanders aspired to inhabit in the 1920s.

Arriving in Auckland from North America in 1920 at the age of 39, the Canadian architect Sholto Smith had already accumulated experience in designing modern office buildings and large houses before his immigration. Significantly, he had two rustic designs for rural lodges in Vancouver to his credit. In Auckland, his signature domestic style was a simplified form of the English Arts and Crafts house - a hunting lodge for the suburbs. Like his contemporary JW ChapmanTaylor, Smith was of English parentage, and he was familiar with the work of Charles Voysey and Robert Mackay Baillie Scott through his visits home as well as the 
publication of their designs in the professional English architectural journals which he received. Like all young North American architects of his era, he owned copies of the numerous popular books on the British house (most of which were published in the years 1900-12), subscribed to The Studio and visited the World's Columbian Exposition in Chicago in 1893. ${ }^{1}$ His Auckland architecture is reminiscent of Californian Arts and Crafts architecture, particularly the over-hanging eaves reminiscent of Swiss chalets, mountain architecture and mission buildings but also has a distinctively South Pacific inflection.

Sholto Smith's major contribution to Arts and Crafts Auckland, the house he designed as a gift for Phyllis Hams on the occasion of their marriage on 3 March 1925, was named "Colwyn" to memorialise their Welsh meeting place. On the crest of the hill above fashionable St Heliers beach, "Colwyn" was a well-placed advertisement for his domestic architecture. A little bit of Olde Englande recreated in the eastern suburbs for his homesick new wife, this large house epitomised the romantic archetype of the

${ }^{1}$ Their work was also published in The Magazine of Art, The Magazine of Fine Arts, the Journal of Decorative Arts and Country Life.
Cotswold cottage. Despite major recent alteration, it remains a fine example of the type of Arts and Crafts dwelling that well-todo Aucklanders aspired to inhabit in the 1920s. Designing with nature, art, handcrafts and the spiritual in mind, Sholto Smith was responsible for many of the Tudor Revival house designs built during the building boom of the 1920s in Auckland.

Sholto Smith's father was an English civil and mining engineer. He and his wife Isabella Holmes Hurle were living in Nice so that Joseph Burley Smith could supervise the construction of a sea wall in front of the famous Promenade Anglais that was built after Nice was annexed by France in 1860. This was how Sholto Smith came to be born in the Alpes Maritimes at midnight on 25 January 1881. ${ }^{2}$ His parents returned to England and lived there until the late 1880s when they emigrated to Canada, and took up residence in Glen Almond, in Quebec so that Joseph Smith could manage to AngloContinental Guano Works at Squaw Hill Mine. $^{3}$ After a dispute over boundaries, Anglo-Continental abandoned the mine in

2 Smith, Family history manuscript.

3 Hogarth "Stanislas Franchot (1851-1908) and His Buckingham Mines."
July 1892 and the Smith family moved to Montreal. The 20-year-old Sholto Smith is recorded as having passed his preliminary examination for a license to practise as an architect in the Architectural Association examinations in Montreal in 1901. ${ }^{4}$ By June 1905, he was joint secretary with R Charbonneau of the Sketching Club of the Province of Quebec Association of Architects ${ }^{5}$ and reported on the contrast of styles between two new buildings in Montreal - Percy Nobbs' McGill Students Union Building and McKim, Mead and White's Mount Royal Club - in following year's edition of The Canadian Architect and Builder.

In January 1907 Sholto Smith was in partnership with William Alexander Elliott (1866-1957) a successful Ontario-born architect who had already established architectural practices in Anaconda, Montana and Brandon in Manitoba and was looking for opportunities to expand into areas which were undergoing rapid development. ${ }^{6}$ They tendered successfully for a central fire station building for Moose Jaw in March of 1907 and the building was constructed in brick with a

\footnotetext{
4 "The Licensing of Architects: Notes" p 86.

5 "McGill Student Union and Mount Royal Club" p 84.
}

6 "William Alexander Elliott" n.p. 
sandstone trimming with Elliott supervising as Smith had already left for Vancouver. ${ }^{7}$

Arriving on the West Coast in mid summer 1908, he established an office with William Alexander Doctor in the downtown Fairfield Buildings, where many of Vancouver's Arts and Crafts Architects had offices. ${ }^{8}$ The intention was to reap the benefits of another building boom as Vancouver doubled in size to nearly 80,000 people by 1909 . He married Cora Lilley Woodward, who was the youngest daughter of the owner of Woodward Department Stores Ltd, Charles F Woodward (1842-1937), in the West Vancouver Methodist Church on 7 April 1909. ${ }^{9}$ He was also broadening his professional associations at this time: his name is listed as one of those at the inaugural meeting of the British Columbia Association of Architects held in the Vancouver Board of Trade Rooms on 29 January 1909.10 At that meeting, Frances Rattenbury was elected president, with Samuel Maclure, Robert Mackay Fripp and Sholto Smith appointed to

${ }^{7}$ Fulton "Sholto Smith" p 73.

${ }^{8}$ Henderson's City of Vancouver Directory (1909) p 942.

${ }^{9}$ Harker The Woodwards p 65.

${ }^{10}$ Institute of Architects Quarterly Bulletin quoted, Fulton "Sholto Smith" p 74. an entertainment committee. By 1910 both Maclure and Sholto Smith were operating their practices from offices in the newly completed Winch Building, but this cosy arrangement was shortlived as Sholto Smith soon went into partnership with William Douglas Bamford Goodfellow, the son of an eminent New Westminster architect, William Goodfellow (1847-1915) opening an office in 14th Street in 1910. ${ }^{11}$

Goodfellow and Smith's most important building was a 40-room lodge for two Vancouver entrepreneurs, Benjamin Dickens and Alvo von Alvensleben at Indian Arm at the end of Burrard Inlet. It features many aspects of the Arts and Crafts sensibility that would become evident in his New Zealand buildings: the gabled roof is steep with every fourth course of shingles emphatically doubled, and it reaches out to become an overhanging porch shelter which returns around the gable ends. Like the hotels designed for Yosemite by Californian Arts and Crafts architects, the materials referenced the miners' shanties of the nineteenth century which were distinguished by walls built of

${ }^{11}$ Sholto Smith of Smith and Goodfellow first appear at 2216 14th Street, Vancouver, Henderson's City of Vancouver and North Vancouver Directory p 1131. half-board logs chinked with clay and shingle rooves. The directness achieved by the use of these natural materials (Von Alvensleben's German connections meant that this property was seized by the Custodian of Enemy Property with the outbreak of World War One in 1914 but it survives to the present day as an outpost for the Royal Canadian Yacht Club ${ }^{12}$ ).

The success of this building was followed with another commission for a backwoods retreat, this time a skiing lodge on the top of Grouse Mountain in Vancouver in 1911. But his opportunities seemed limited despite these two commissions, as competition for work in Vancouver was intense, and Sholto Smith decided to move his family back to Moose Jaw which was still booming. ${ }^{13}$ Here he completed a building for the Moose Jaw Cold Storage Company in Manitoba Street West in 1912 (demolished 1964), an Industrial Hall for the Board of Trade built on Main Street North at Manitoba Street East (demolished 1922), St Barnabas Anglican Church 1913 (demolished 1935) and an apartment and business block for Harold Matthews, a confectioner and real

12 Armitage "Wigwam Inn" n.p.

13 The family by now included a daughter, Phyllis Geraldine, born in Vancouver on 6 November 1910. See Fulton "Sholto Smith" p 76. 
estate agent, which was named Victoria Hall and opened in 1913. Of these, the Aquatic Club (opened in 1913), has a marked "Elizabethan" effect with half-timbering in the jerkinhead gables. There was also a commercial commission, the Douglas Building (1914) and a residence for J Holmstead at Wellesley Park in 1914 (demolished 1981). ${ }^{14}$

On 12 April 1913, Sholto Smith and his wife Peg (who was pregnant with their second child, a son) went on holiday to Vancouver where she remained while Sholto returned to Moose Jaw. Building slowed with the withdrawal of British capital investment in the lead up to World War One, and Sholto Smith was keen to join up when war was declared. He enlisted on 23 September with the 11th Battalion of the Canadian Expeditionary Forces, leaving for overseas on 4 October 1914 at the age of 33 years. ${ }^{15}$ During his five years overseas service, he met Phyllis Mary Hams while on leave in Colwyn Bay, North Wales, and he corresponded with her after she emigrated with her family to New Zealand in 1921. Sholto Smith returned to Moose Jaw on

\footnotetext{
14 "Sholto Smith" n.p.

${ }^{15}$ Fulto "Sholto Smith" p 82.
}

28 October 1919 but was unsettled, and soon left for Auckland, New Zealand. ${ }^{16}$

Smith arrived in Auckland on 17 March 1920 and immediately joined the practice of Thomas Coulthard Mullions (1878-1957) and C Fleming McDonald. The latter had been the architect of the original Masonic Hotel in Napier (1897), and the firm originally specialised in hotels and commercial architecture using modern materials including reinforced concrete, but dressing the modernist structure with historicist references. With the new Canadian arrival on board, the first collaborative design was an entry in the public competition for a new Arts Building for Auckland University College in 1920. Forty-four perspectives were submitted for this competition and Mullions, Smith and McDonald was one of the six architectural firms that were invited to submit final architectural designs in 1921. Their architectural perspective shows a design for a building that made reference to Victorian Gothic collegiate architecture with a Californian inflection. Symmetrical, and intended to be in either stone or concrete, the building was to have a Marseilles tile roof

${ }^{16}$ Smith, Family history manuscript. with inset dormer windows. Two storeyed, the block was to have large arched windows on the upper storey and rectangular multipaned windows below, interspersed with buttresses. North-facing bay windows bulge out beneath sharply pointed gables at each end of the building. Alert to the transportation requirements of the modern age, a detached gate was intended provide vehicle access to the grounds beneath its pointed arch. Dominating the design is the square decorated bell tower topped by four elaborate crockets, with a further four of these vertical elements adorning the ridge line of the north and south wings. Like the central tower of an English cathedral, this counters the horizontal emphasis of the design. Crockets like these would later feature in the designs for Shortland Flats and Chancery Chambers as a kind of shorthand for the skyscraper Gothic style.

After McDonald's death, Sholto Smith became a partner in the firm and encouraged Thomas Mullions to move into residential property development in central Auckland: Shortland Flats Ltd was a commercial venture where the architects formed a company on 22 December 1922, each owning a number of shares in the building which comprised 24 flats designed to 
generate rental income. Shortland Flats, which has been described as Auckland's smallest example of skyscraper Gothic evidences Sholto Smith's typical regard for the past but combined with modern construction methods and conveniences. Though it has many neo-Gothic finishes, such as shields emblazoned with a separate numeral making up the date of construction, 1923, it has large north-facing windows and is of reinforced concrete construction, poured onsite by the prominent Auckland construction company Noel Cole Ltd. Yet it emulates stone, and hides its other modernist indicator, a flat roof, behind a parapet with neo-Gothic decoration. Its other modern appurtenances include an electric lift, installed by the Electric Construction Company whose manager George Thorburn was an investor in the building, and open porches for each of the 24 flats. The entrance hall on the interior features luxury finishes such as a diaper patterned marble tiled floor, varnished oak panelling with cornices and a ribbed, arched ceiling and polished brass handrail. Glazing to the exterior initially bore the name of the building in gilt Gothic lettering. The stairway features a star of David pattern banister, carved oak handrail and square newel posts, each with four shields matching the shields on the exterior of the building.

Several other inner-city Auckland buildings designed by Sholto Smith including the Waitemata and Manukau Council building on the corner of Shortland and Princes Street, Chancery Chambers in O'Connell Street and the Lister building on the corner of Victoria and Lorne Streets, are also reinforced concrete constructions with North American inflections. The Lister Building, named for the pioneer of antiseptic, shows a knowledge of the principles of Beaux-Arts architecture. Sholto Smith was very familiar with the filtering of classical Greek and Roman elements through the Parisian Ecole des Beaux-Arts popularised by the American urban architects McKim, Mead, White in the early twentieth century as part of the City Beautiful movement in New York. Their Manhattan Municipal Building, built 1909-15 had been the first to incorporate a New York subway station in its basement and features the same rustication on the corners, dentilled cornice and differentiation of the upper floors as the Lister Building. Chancery Chambers dates from 1923-24 ${ }^{17}$ and originally was

${ }_{17}$ Published in the "Chancery Chambers, O'Connell Street" p 17 and "New Chancery Building" p 12. intended to have an elaborate set back Gothic top, referencing what was the tallest building in the world from 1913-30, the 241 metre Woolworth Building designed for 233 Broadway by Cass Gilbert in New York.

"Santa Barbara" (built in 1923 and demolished in 1989) was a low-rise development in Grafton proceeded from the Shortland Flats development. It shows the influence of the Spanish Mission style, with a shallow-pitched roof clad in Marseilles tiles, with twin miniature shingled lantern-tower motifs at the crest. The exterior walls have a rough-cast finish over concrete. Boosted by the PanamaCalifornia Exposition of 1915, Mission Style architecture was available for revival and reinterpretation in the South Pacific context due to the similarity of climate between California and New Zealand. The original Franciscan missions of the eighteenth century had enclosed courtyards with thick arches springing from piers, adobe walls and large unadorned plaster surfaces with wide eaves and clay roof tiles. All the units at Santa Barbara in Grafton faced into a central courtyard and the windows were glazed with leadlights with traditional diamond panes. Santa Barbara is distinguished by having 17 circular bosses studded around the exterior 
entrance and an abbreviated wooden portcullis, medievalising details which are rarely found in Mission Revival style architecture in California. Typically eclectic, the design features of these flats show Sholto Smith's eclecticism and his simultaneous interest in both modern and historical architectural traditions.

He was keen to adapt concrete to small-scale domestic use but always disguised this modern material with a plaster finish. Rather than leaving façades plain, he decorated them with historicist detail. A photograph of an unfinished house from 1925, the residence for Mr Hicks at 61 Mt Roskill Road shows the concrete construction before the stucco is applied. A comparison with a cottage by Gummer and Ford of the same period in Gorrie Avenue in Epsom shows various similarities: lattice windows, ornamental window shutters, an arched entrance and Winstone Marseilles tile roofing, but the Sholto Smith design shows a greater tendency to picturesque asymmetry with the prominent external chimney massed at the front of the house adjacent to the front door as in the Cottage Revival style popular in California at the time. Copper drainpipes are carried down the front façade (just as they were at Santa
Barbara, either side of the entranceway) whereas Gummer and Ford tuck theirs behind the built-up surrounding for the door. The Sholto Smith approach to incorporating drainpipes as vertical linear elements therefore makes a decorative feature out of the functional necessity.

In the larger house, "Roscommon" at 16 Landscape Road, Mount Eden, designed for William Taaffe, a direct descendant of Patrick Taaffe who held land in the barony of Roscommon in Ireland, Sholto Smith played with English Tudor references. As well as this historicising, he included a porte cochere, for the owner's car to be able to be driven up to the main door of the house. The external halftimbering seen here is also a feature of "Lamorna" a house for $\mathrm{H}$ Roskilly at 13 Papahia Street, Parnell and the four bedroomed, 230 square metre house built in 1926 for WF Hawely at 6 Ladies Mile which is distinguished by a circular turret to the stairwell that is externally expressed. Like Shortland Flats, this last house has a dark oak panelled entrance hall, but unusually for Sholto Smith houses is timbered, with a dark stain and white window sills, and originally finished with a steeply pitched Marseilles tile roof.
Sholto Smith's decision to emigrate to New Zealand seems to have been precipitated by a memorable encounter with a woman who would later become a celebrated pianist for the Auckland radio station 1YA, Phyllis Mary Hams (1895-1974). Sholto Smith had met Hams during World War I while he was on leave from the Canadian Expeditionary Force and visiting Colwyn Bay, North Wales. She was barely 20 at the time and throughout his overseas service and return to Moose Jaw, they maintained a correspondence. After his divorce from his first wife Peg (Cora Lilley Woodward) he wed Phyllis in a Methodist ceremony in Auckland on 3 March 1925. Before he even had left Canada, he drew his vision for the perfect house which he named "Dreamwold."

Half-timbered with a shingled roof which mimics the look of thatch, dormer windows above and casement windows below, both with small panes, "Dreamwold" is a fanciful vision. It is even set in a picturesque garden with lake and a strolling peacock. The dream house is bordered by a garden of climbing and flowering plants and approached by paved pathways through a mown lawn. Its name evokes the original Cotswold Cottage, built at the time of the Norman Conquest in 1066. 
The name is derived from "cot" meaning cottage and "wold" meaning wood: hence cottage in the wood. It was an entirely romantic idea of a cosy, storybook house which in its scale and massing recalls the childhood home of Anne Hathaway, the wife of William Shakespeare in Warwickshire about a mile west of Stratford-upon-Avon. This 12-roomed farmhouse was built some time prior to the fifteenth century, and has multiple chimneys and visible timber framing, which are also evident in the design of "Dreamwold" and are the hallmarks of vernacular Tudor Style architecture.

"Colwyn," named for the bay in Wales where he met his second wife-to-be, was Sholto Smith's idea for "Dreamwold" translated to the South Pacific. The house was his wedding present to Phyllis. The built design maintains the Anne Hathaway cottage references right down to the text on the wooden mantelpiece over the fireplace. The quote inscribed there is taken from the beginning of Shakespeare's sonnet 57: "Being your slave, what should I do but tend upon the hours and times of your desire?" His design featured a detached garage at the front with roller door, and at the back a sunny separate studio for his wife's piano teaching career to continue. The rear elevation is more picturesquely asymmetrical with north-facing windows in the bedrooms and living areas, and a balcony off the master bedroom giving a view to the beach. Despite its half timbering and low tiled roof, it is of concrete construction with brick rustication emphasising the entrance and lower-storey windows.

In the design of this house can be seen the culmination of Sholto Smith's architectural inheritances, his link to the Tudor Revivalism of Canadian colleagues such as Samuel Maclure as well as the English Arts and Crafts modernists Charles Voysey and MH Baillie Scott. In particular, "Colwyn" has open planning in its main living areas in a similar manner to Baillie Scott's Corrie Wood at Letchworth in Hertfordshire. Yet it is also a South Pacific house which admits sunshine and seaviews into its heart. Sadly, Sholto Smith did not live long enough to enjoy his Dreamwold - his health deteriorated throughout the 1930s as a result of gassing in the trenches during World War I. He died at "Colwyn" on 8 July 1936. His legacy of over 100 houses shows an oscillation between historicism and modernism which was entirely consistent with the eclecticism of the interwar period. His love of detail is evident both in the stripped classical formality of a late project such as the former Nestlé building at 109 Ghuznee Street Wellington and his domestic commissions like the house at Rosella Road in Mangere East. His contribution to Auckland's cityscape is both distinctive and enduring and he is deserving of greater recognition for his contribution to popularising the Arts and Crafts style for domestic architecture locally. 


\section{REFERENCES}

Armitage, Doreen "Wigwam Inn" Encyclopedia of British Columbia 2011 http://knowbc.com/ebc/Books/Encyclopedia-of-BC/W/Wigwam-Inn

"Chancery Chambers, O'Connell Street" Builders' Record (December 1923):17.

Fulton, Gordon "Sholto Smith" Society for the Study of Architecture in Canada Bulletin (September 1990) 15(3):68-82. Available: http://sextondigital.library.dal.ca/jssac/bulletin.html\#

Harker, Douglas E. The Woodwards: The Story of a Distinguished British Columbian Family, 1850-1975 Vancouver: Mitchell Press, 1976.

Henderson's City of Vancouver Directory (1910) Part 2. Available at: http://www.vpl.ca/bccd/index.php/browse/title/1908/Henderson\%27 s_City_of_Vancouver_Directory

Hogarth, Donald "Stanislas Franchot (1851-1908) and His Buckingham Mines" Outaouais Heritage Web Magazine (Reprinted with permission from Up the Gatineau! Volume 24)

http://outaouais.quebecheritageweb.com/article/stanislas-franchot1851-1908-and-his-buckingham-mines

"The Licensing of Architects: Notes" Canadian Architect and Builder (1901)14(3):66.

"McGill Student Union and Mount Royal Club" Canadian Architect and Builder (1906) 19(6):84.

"New Chancery Building" New Zealand Building Progress (April 1924):12.

"Sholto Smith" Biographical Dictionary of Architects in Canada, 1800-1950 Available at: http://www.dictionaryofarchitectsincanada.org/architects/view/1314

Smith, Sholto. Family history manuscript in the possession of R. Sholto Smith, Auckland.

"William Alexander Elliott" Biographical Dictionary of Architects in Canada, 1800-1950 Available at: http://www.dictionaryofarchitectsincanada.org/architects/view/1554 